\title{
Gender Role and Decision Making in Soybean Production and Management Practices in Bambasi District, Benishangul-Gumuz Regional State, Ethiopia
}

\author{
Hawa Mehari $^{1^{*}} \quad$ Habtamu Ashagre $^{2} \quad$ Mulu Debela $^{3}$ \\ 1.Assosa Agricultural Research Center, Ethiopian Institute of Agricultural Research, P.O.Box 265, Ethiopia \\ 2.College of Agriculture and Veterinary Science, Department of Plant Sciences, Ambo University, Ethiopia \\ 3.School of Agricultural Extension and Rural Development, Department of Development studies, Ambo \\ University, Ethiopia
}

\begin{abstract}
The purpose of this study was to investigate the role of men and women on soybean production, household and community management; and decision making in soybean production at Bambasi District, Benishangul Gumuz Regional State, Ethiopia. A multi-stage sampling procedure was used to select sample respondents in the study area. Out of thirty eight kebeles (the smallest administrative unit) in the district, ten kebeles which involved in soybean production were selected purposively. Similarly five kebeles were selected by simple random sampling technique. Based on the list of the beneficiaries, households were selected using probabilities proportional to sample size procedure. A total of 136 households of soybean producer farmers ( 78 male headed household (MHH) and 58 female headed household (FHH)) were selected for the study. Primary data were collected through the aid of semi-structured questionnaire, interview and focus group discussion. Descriptive statistics was used to summarize and compare the information obtained in both households. The findings of the study revealed that women and men play a key role in all types of soybean production activities. In FHH women took the lion share of the activities. In MHH, many numbers of men (2.9 on average) were devoted much time (12.5hrs) to clear the land. Preparing the land using oxen was entirely men's activity in both MHH and FHH, while weeding activity was carried out by women. Men were devoted $9.6 \mathrm{hrs}$ in harvesting activity in MHH; however women also virtually share more time in these activities. In FHH more labour and time were devoted by women. Threshing the produce using animal was carried out by men in both households. In equine transport men were the chief of the activity in MHHs and FHHs. Women were over burden in reproductive activities. The result indicated that in $\mathrm{MHH}$, men took the higher position in making the decision of the household. In the same manner in FHH, women made the major decision of the household. Women often work longer hours (15hrs/day in MHH and 16hr/day in FHH) than men $(11 \mathrm{hrs} /$ day) in the households. In conclusion the role of men and women are different, and the significance of women role is not equally valued. Hence, it is recommended to improve gender specific issues and disparities to soybean producers in particular, and to women farmers in general.
\end{abstract}

Keywords: Decision making, Gender role, Soybean production

DOI: $10.7176 /$ IEL/10-1-05

Publication date: January $31^{\text {st }} 2020$

\section{Introduction}

Gender as an interdisciplinary concept refers to women and men, the relations between them, and the institutions that govern these relations (Farre, 2013). Gender relates to socially assigned roles and behaviors attributable to men and women. Gender is useful in analyzing the role, responsibility, opportunity and constraints of different ecological zone, ethnicity, religion, culture, different economic classes and cultural attributes. In almost all societies, women and men differ in their activities and undertakings, regarding access to and control over resources and participating in decision-making (Mohammed and Abdulquadri, 2012).

Gender roles are socially rather than biologically determined; they are fluid and subject to change based on changing norms, resources, policies, and contexts. Every society is marked by gender differences, but these vary widely by culture and can change dramatically within or between cultures over time (Mollel and Mtenga, 2000). Women comprise on average 43 percent of the agricultural labour force in developing countries. The female share of the labour force ranges from about 20 percent in Latin America to almost 50 percent in Eastern and Southeastern Asia and sub-Saharan Africa (FAO, 2011b). If men and women had equal access to productive resources in agriculture, food output in developing countries would increase by between 2.5 and 4 percent - enough to pull 100-150 million people out of hunger. But in many countries, existing and historically based cultural discrimination against women means that they have less right than men to own or hold land or to make decisions about their lives (FAO, 2011a).

Agriculture is a key driver of Ethiopia's long-term growth and food security. Agriculture supports more than 70 percent of the population, constitutes 34.8 percent of Gross Domestic Product (CIA, 2019). Rural women in Ethiopia represent a tremendous productive resource in the agricultural sector. They are major contributors to the 
agricultural workforce, either as family members or in their own right as women heading households (Aregu et al., 2011). Fifteen percent of Ethiopian farming populations are women. It is estimated that the average working day of 12-14 hours, much of it spent in hard physical labour (Haregewoin and Emebet, 2003). Removing gender disparity and ensuring gender equality and women's empowerment is the key to accelerated economic growth and social development (Chanyalew et al., 2010).

Ethiopian women face major constraints to access resources, assets and basic services such as land, credit and agricultural inputs critical to decent livelihoods compared to their male counter parts. The evidence demonstrates that any program dealing with food security issues must address gender inequalities as one of many strategies to tackling the underlying causes of food insecurity (CRS, 2013). Traditionally men gain access to land, except female heads of households. Ploughing is designated to men, and women owning land hire men for ploughing to get only a portion of the output. With the exception of female heads of households, women have minimal role in decisions related to land distribution and agricultural production (Haregewoin and Emebet, 2003).To boost Agricultural production and productivity the vital role of men and women is needed. Accordingly, this study was initiated to assess gender role and decision making among $\mathrm{MHH}$ and $\mathrm{FHH}$ of soybean producers in Bambasi district.

\section{Research Methodology}

\section{Description of the study area}

Bambasi district is among the seven districts found in Assosa Zone of Benishangul Gumuz Regional States. It is located at a distance of $625 \mathrm{Km}$ from Addis Ababa (Fig 1). It has an annual rainfall ranges from 1350-1450mm with average temperature of $28{ }^{\circ} \mathrm{C}$. The district has $85 \%$ lowland and $15 \%$ highland agro-ecology zones. Maize, Sorghum, Soybean, Finger millet, Niger and Haricot bean are the major crop grown in district. Livestock reared by most of the people include Cattle, Sheep, Goat, Donkey, Mule and Poultry (BDAO, 2016).

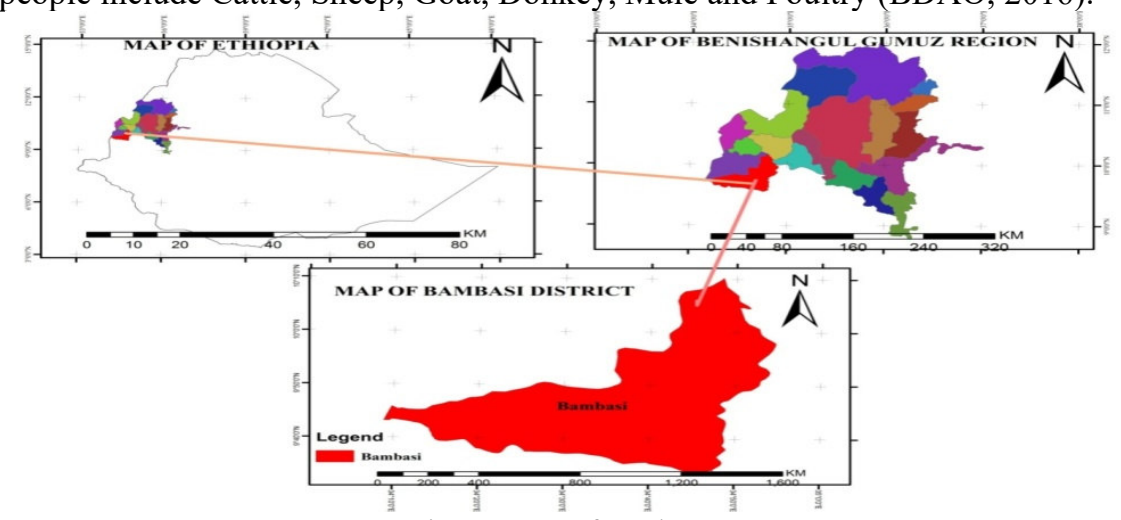

Fig 1. Map of study area

\section{Sample Design and Sample Technique}

A multi-stage sampling procedure was employed to select sample households. At the first stage Bambasi district was selected purposively because of its high potential for soybean production. In the second stage from a total of thirty eight kebeles in the district ten kebeles were selected purposively according to the intensity of soybean cultivation within the same agro ecology. At the third stage five were selected out of ten kebeles using simple random sampling techniques. Finally according to the list of household obtained from each kebele 78 MHHs were selected based on probability proportional to sample size procedure. Due to the small number of FHHs, to make adequate representation of the sample seventy percent $(70 \%)$ of the sample size was taken into account; accordingly 58 FHHs were taken for the purpose of comparison. Based on Yamane's (1967) formula at 95\% confidence level and $8 \%$ precision level a total of 136 households were selected by simple random sampling techniques.

$$
n=\frac{N}{1+N\left(e^{2}\right)}
$$

Where $\mathbf{n}$ is sample size, $\mathbf{N}$ is population size, $\mathbf{e}$ is level of precision. 
Table 1. Distribution of sample households

\begin{tabular}{|l|c|c|c|c|c|c|}
\hline \multicolumn{1}{|c|}{} & \multicolumn{3}{|c|}{ Number of households } & \multicolumn{3}{c|}{ Number of respondants } \\
\hline Study Kebele & Total & MHH & FHH & Total & MHH & FHH \\
\hline Mender 46 & 233 & 215 & 18 & 31 & 18 & 13 \\
\hline Mender 49 & 224 & 214 & 10 & 25 & 18 & 7 \\
\hline Sonka keshmando & 256 & 235 & 21 & 35 & 20 & 15 \\
\hline Dabus & 142 & 130 & 12 & 19 & 11 & 8 \\
\hline Total & 144 & 123 & 21 & 26 & 11 & 15 \\
\hline
\end{tabular}

\section{Data collection and analysis}

The primary data were collected from the target respondents with the aid of questioner, interview and focus group discussion. Both qualitative and quantitative data were analyzed using STATA 13 Software. Descriptive statistics like mean and percentage were used for interpretation of the data.

\section{Result and discussion}

\section{Socio-economic characteristics of the respondent}

The result of the study indicates that the average age of male household heads was 48.7 years and for female heads was 46.6 years which is regarded as the active productive age. It also implies that soybean production activities are in the hands of this age group which constitute the active population. (Adisa and Balogun, 2013). At the same time $46.55 \%$ FFH was divorced followed by $39.66 \%$ widowed and $13.79 \%$ married while $100 \%$ of MHH was married (Table 2). This further suggests that most of them had responsibilities to discharge to their families (Balogon et al., 2014.) About 63.24\% of the sample households were Amhara, while the rest i.e. 22.79\%, 8.82\% and 5.15\% number of the households accounted for Berta, Tigre and Oromo, respectively. In terms of religion about $56.62 \%$ of respondents were Muslim, $41.91 \%$ were Orthodox and $1.47 \%$ of respondents were Protestant.

The level of education is important to mitigate most of the challenges in life. The knowledge attained through level of education is important to determine the decision of household head and to capacitate the social and economic well-being of the individual in the house hold. About 34.62\% male headed and $67.24 \%$ female headed households were illiterate (Table 2). The proportion of MHH who read and write was $16.67 \%$, whereas $12.07 \%$ was FHH. The proportion of male headed who attended grade $1-4$ was $17.95 \%$, while that of female headed household was $12.07 \%$. The rest of 16.67 and $11.54 \%$ of male headed, and 6.90 and $1.72 \%$ of female headed households attend grade 5-8 and 9-10, respectively. The remaining 2.56 \% of MHH attended grade 11-12. This implies that more males had formal education than females (Agada, M.O and Ejembi E.P., 2010). Understanding the literary and skill level of producers is important in packaging the information and technology dissemination and education to them (Regasa, 2012).

The average annual cash income generated from farm and off farm activities for MH households was 19778.69 birr and for FH households was 10355.76 birr. The proportion of income earned from off-farm activities was accounted 1405.13birr for MHH and 561.21birr for FHH. This result confirmed that in the study area incomes of women in all cases are lower than male. The total number of family members of the sample households was about 662, out of which the share was 439 in MHH and 223 in FHH. Large households will be able to provide family labour that might be required by improved soybean technologies. Thus, household size would be expected to increase the probability of adopting improved soybean technologies (Adiisa and Balagon 2013). The major crops cultivated in the area were Soybean, Sorghum, Maize, Teff, Chickpea, Pepper and Noug. The average total land areas under these crops were about 1.77 ha for MHH and 1.41 ha for FHH. The households produce soybean for cash purpose. The average farming experience for MHH was 25.15 years and 22.15 years for FHH. Regarding to soybean production, the average years of experience was 4.97 years in MHH and 3.33 years in FHH. This implies that male farmers had longer years of soybean farming experience relative to females (Agada, M.O and Ejembi E.P., 2010). The result shows that the farmers were relatively new in soybean farming, and thus would need close attention from the extension system for desired improvement in their production tasks (Balagon et al., 2014). The length of experience is probably an indicator of a person's commitment to the chosen career (Ejembi et al., 2006). 
Table 2. Socio-economic characteristics of respondents in the study area

\begin{tabular}{|c|c|c|c|}
\hline Category & Variables & $\mathrm{MHH}$ & $\mathrm{FHH}$ \\
\hline Average age & Age & 48.7 & 46.6 \\
\hline \multirow{3}{*}{ Marital status $\%$} & Divorced & 0 & 46.55 \\
\hline & Widowed & 0 & 39.55 \\
\hline & Married & 100 & 15.52 \\
\hline \multirow{6}{*}{ Education \% } & Illiterate & 34.62 & 67.24 \\
\hline & Read and write & 16.67 & 12.07 \\
\hline & $1-4$ grade & 17.95 & 12.07 \\
\hline & $5-8$ grade & 16.67 & 6.90 \\
\hline & $9-10$ grade & 11.54 & 1.72 \\
\hline & $11-12$ grade & 2.56 & 0 \\
\hline \multirow{2}{*}{ Annual cash income in birr } & Farm and off farm activities & 19778.69 & 10355.762 \\
\hline & Off farm activities & 1405.13 & 561.21 \\
\hline Household & Family Member & 439 & 223 \\
\hline $\begin{array}{l}\text { Land (ha) under major } \\
\text { crops }\end{array}$ & $\begin{array}{l}\text { Soybean, Sorghum, Maize, Teff, chickpea, pepper and } \\
\text { Noug }\end{array}$ & 1.77 & 1.41 \\
\hline \multirow{2}{*}{ Average experience } & Farming experience & 25.15 & 22.15 \\
\hline & Soybean farming experience & 4.97 & 3.33 \\
\hline
\end{tabular}

Table 3. Respondents Percent on the basis of ethnicity and religion

\begin{tabular}{|l|l|c|}
\hline Category & \multicolumn{1}{|c|}{ Variables } & MHH and FHH households \\
\hline \multirow{4}{*}{ Ethnicity\% } & Amhara & 63.24 \\
\cline { 2 - 3 } & Berta & 22.79 \\
\cline { 2 - 3 } & Tigre & 8.82 \\
\cline { 2 - 3 } & Oromoo & 5.15 \\
\hline \multirow{3}{*}{ Religion \% } & Muslim & 56.62 \\
\cline { 2 - 3 } & Orthodox & 41.91 \\
\cline { 2 - 3 } & Protestant & 1.47 \\
\hline
\end{tabular}

Table 4. Type of crops and quantity of production by sample households

\begin{tabular}{|l|c|c|c|c|c|c|c|c|}
\hline \multirow{2}{*}{\multicolumn{1}{c|}{ Crop }} & \multicolumn{3}{|c|}{ MHH } & \multicolumn{5}{c|}{ FHH } \\
\cline { 2 - 9 } & $\%$ & Area & Qt & $\%$ & Area & Qt & t-test & P-valeu \\
\hline Soybean & 100.00 & 0.42 & 8.29 & 100.00 & 0.44 & 6.65 & $1.3695^{*}$ & 0.0866 \\
\hline Sorghum & 97.44 & 0.52 & 9.95 & 82.76 & 0.3 & 5.77 & $3.0697^{* * *}$ & 0.0013 \\
\hline Maize & 85.9 & 0.29 & 7.53 & 68.97 & 0.28 & 4.89 & $1.9013^{* *}$ & 0.0297 \\
\hline Teff & 17.95 & 0.04 & 0.26 & 1.72 & 0.002 & 0.052 & $1.8323^{* *}$ & 0.0346 \\
\hline Chickpea & 12.82 & 0.024 & 0.12 & 5.17 & 0.003 & 0.043 & $1.377^{*}$ & 0.0854 \\
\hline Pepper & 51.28 & 0.28 & 3.04 & 44.83 & 0.23 & 1.34 & $2.1476^{* *}$ & 0.0168 \\
\hline Noug & 53.83 & 0.22 & 1.04 & 43.1 & 0.125 & 0.65 & $1.7794^{* *}$ & 0.0387 \\
\hline
\end{tabular}

Source: Own survey, $2017 \mathrm{NB}: * * *, * * *=$ Significant at $1 \%, 5 \%$ and $10 \%$ probability level

\section{Gender division of labour in soybean production and management practices}

In the process of producing crops for food and cash, men and women have distinctive role. Women and men in Bambasi district have separated gender role specified by age and sex (Table 5). The survey result showed that both men and women took active part in soybean production activities. The households reported that the first activity in soybean production was started from the month of March. Women and men have involved in different agronomic practices until the marketing process.

Land clearing was carried out by the members of the household in both MHH and FHH. The share of the activities was different among the members including the time shared among them. In MHH, men devoted more time $(12.5 \mathrm{hr})$ to clear the land, while women share few hours $(4.1 \mathrm{hr})$ in the activity (Table 5). To some extent youths also participated in the activities. In FHH, women take the lion share in this activity by devoting $10.9 \mathrm{hrs}$ with the involvement of youth and children to some extent. Land preparation was carried by hand digging and oxen plough. Hand digging was totally carried out by men and women in MHH, while in FHH the activity was done by women. There was no difference among them for the time devoted to the activities. However, in preparing the land using oxen men were entirely undertake the activity in both MHH and FHH. In the study area women never ploughed the land using oxen. The study clearly demonstrated that men devote most of their time in 
ploughing the land, while clearing of the land was not solely to men activities. Row planting of Soybean was carried out by the entire members of the households in both MHH and FHH. In both households almost the activities was performed by men and women. A considerable percent of children and youth devoted their time in the activities in both households. Moreover bird scaring in soybean production activities was mostly carried out by children in both MHH and FHH. A minimal number of men, women and youth were also performing the activities in both households. Soybean hoeing was undertaken mostly by men and women in MHH, however in FHH, this activity was undertaken by women. In both households children and youth also participated. Although all members of the household participated in the weeding activities, women carried most the activities and devoted more time than other members in the household. In MHH all the family members participated in harvesting activities; however more men involved with devotion of more time. Moreover, women spent long hours for the same activities. Similarly more labour and time devoted by women in FHH.

Threshing is carried out by hand and animal in some rare case using machine. In threshing by hand and animal, men and women were participated in the activities; however their difference was the variation of time devoted in the activity (Table 5). Nevertheless, machine threshing was the sole activity left to men in MHH. Winnowing was carried out by all the members of both MHH and FHH. Among the members the most time was devoted by men and women in MHH; and it was by women and youth in FHH. Transporting of the produce was made by equine, and backside of human. In the activity of equine transport men were the chief of the activity in MHHs and FHHs. In this activity women in MHHs were not take part, while women in FHH take some part in the activity. Also members in both households participate in the activities of transport by backside. In this activity men and women were taken the most shares than other members of MHH. In FHH women took most part of the activities than others. Also youth took active part than other member of the household. This finding is similar to findings by Asres et al., (2015), USAID (2013), Lal and Khurana (2011), World Bank (2010), Ardayfio-Schandorf, E., and Awumbila, M. (2000), Ogato et al., (2009), Hanna (1990) and Frank (1999) that states women are thoroughly involved in all aspects of agricultural production process.

Table 5. Gender role in soybean production in Bambasi district

\begin{tabular}{|c|c|c|c|c|c|c|c|c|c|c|c|c|c|c|c|c|}
\hline \multirow{3}{*}{ Activities } & \multicolumn{8}{|c|}{ MHH } & \multicolumn{8}{|c|}{ FHH } \\
\hline & \multicolumn{2}{|c|}{ Male } & \multicolumn{2}{|c|}{ Female } & \multicolumn{2}{|c|}{ Children } & \multicolumn{2}{|c|}{ youth } & \multicolumn{2}{|c|}{ Male } & \multicolumn{2}{|c|}{ Female } & \multicolumn{2}{|c|}{ Children } & \multicolumn{2}{|c|}{ Youth } \\
\hline & Average & $\begin{array}{l}\text { Time } \\
\text { (hrs) }\end{array}$ & Average & $\begin{array}{l}\text { Time } \\
\text { (hrs) }\end{array}$ & Average & $\begin{array}{l}\text { Time } \\
\text { (hrs) }\end{array}$ & Average & $\begin{array}{l}\text { Time } \\
\text { (hrs) }\end{array}$ & Average & $\begin{array}{l}\text { Time } \\
\text { (hrs) }\end{array}$ & Average & $\begin{array}{l}\text { Time } \\
\text { (hrs) }\end{array}$ & Average & $\begin{array}{l}\text { Time } \\
\text { (hrs) }\end{array}$ & Average & $\begin{array}{l}\text { Time } \\
\text { (hrs) }\end{array}$ \\
\hline Land clearing & 2.9 & 12.5 & 0.5 & 4.1 & 0 & 0 & 0.5 & 3 & 0.7 & 4.4 & 1.2 & 10.9 & 0.1 & 1.1 & 1.3 & 5.2 \\
\hline Hand digging & 0.1 & 2.5 & 0.1 & 2.5 & 0 & 0 & 0 & 0 & 0 & 0 & 0.1 & 2.5 & 0 & 0 & 0 & 0 \\
\hline First oxen plough & 1.9 & 14.6 & 0 & 0 & 0 & 0 & 0 & 0 & 1.2 & 11.9 & 0 & 0 & 0 & 0 & 0.5 & 5 \\
\hline Second oxen plough & 1.5 & 9.4 & 0 & 0 & 0 & 0 & 0 & 0 & 0.9 & 6.5 & 0 & 0 & 0 & 0 & 0.3 & 3 \\
\hline Raw planting & 1.7 & 14.2 & 1.6 & 12.7 & 0.7 & 4.1 & 1.3 & 8 & 1.6 & 8.7 & 1.8 & 14.7 & 0.6 & 5.4 & 1.4 & 7.5 \\
\hline Bird scaring & 0.3 & 5.4 & 0.1 & 0.4 & 0.7 & 11.8 & 0.3 & 3.9 & 0.3 & 0.5 & 0.1 & 3.1 & 0.7 & 14.2 & 0.3 & 4.8 \\
\hline Hoeing & 2.5 & 14.1 & 2.1 & 15.7 & 0.7 & 5.3 & 1.3 & 6.5 & 0.8 & 5.1 & 2.5 & 18.6 & 0.6 & 7.7 & 1.6 & 8.7 \\
\hline Weeding & 1.3 & 6.2 & 2.2 & 11 & 0.5 & 3.6 & 1.3 & 6.1 & 0.7 & 1.6 & 2.5 & 13.4 & 0.5 & 4.6 & 1.1 & 6.8 \\
\hline Harvesting & 2.8 & 9.6 & 1.2 & 7 & 0.5 & 1.8 & 1.1 & 4.1 & 1.6 & 4.9 & 2.1 & 12 & 0.4 & 2.7 & 1.2 & 6 \\
\hline Threshing hand & 1.6 & 6.7 & 0.6 & 2.8 & 0.1 & 1.3 & 0.6 & 1.8 & 1.3 & 3.5 & 1.7 & 4.8 & 0.3 & 0.6 & 0.7 & 3.9 \\
\hline Threshing with animal & 1.7 & 3.4 & 0.1 & 0.7 & 0.2 & 0.5 & 0.3 & 0.9 & 1 & 2.1 & 0.3 & 1 & 0.1 & 0.5 & 0.4 & 1.2 \\
\hline Machine threshing & 0.1 & 0.1 & 0 & 0 & 0 & 0 & 0 & 0 & 0 & 0 & 0 & 0 & 0 & 0 & 0 & 0 \\
\hline Winnowing & 2.5 & 6.3 & 1 & 3.1 & 0.2 & 0.4 & 0.5 & 1.5 & 1.7 & 3 & 1.8 & 5.7 & 0.1 & 0.6 & 0.8 & 3.3 \\
\hline Equine transporting & 1 & 2 & 0 & 0 & 0 & 0 & 0.1 & 0.1 & 0.6 & 0.5 & 0.1 & 0.1 & 0 & 0 & 0.1 & 0.4 \\
\hline Transport by human & 0.5 & 0.9 & 0.3 & 0.6 & 0 & 0 & 0.1 & 0.3 & 0.1 & 0.2 & 1.1 & 1.8 & 0.1 & 0.2 & 0.5 & 0.9 \\
\hline
\end{tabular}

\section{Reproductive activity}

Reproductive and domestic tasks are the responsibility of women in most of the society. These household chores confirmed to women include: cleaning the house, cooking, fetching water, collecting fire wood, child care, washing cloth, boiling coffee/tea, cleaning utensils, buying food items, buying utensils, and care for sick person (Table 6).These tasks are frequently done by women and female children are assisting them when she reaches certain age.

House maintenance was the activities performed by men in MHH and FHH. In this activity women assist in collecting and bring materials for construction. In fencing activity, the responsibility was left to men in $\mathrm{MHH}$ and women were assisting in bringing the material for fencing activity. In FHH women and men are responsible for construction activity. Women in MHH and FHH are over burdened with domestic and reproductive activities; the burden was more acute for women in FHH. The household members of FHH are small in number and shoulder the activity left to them. As a result women in general and soybean producing farmer in particular were less productive as compared to their male counterparts. This finding is similar to findings by Fajarwatia et al., (2016) that states most of the housewives are involved in the reproductive work. Also the finding is similar with the study conducted by Ogato et al., (2009) in Ethiopia which confirmed that females' contribution to reproductive work at household level is very large. The findings of Lal and Khurana (2011), which conducted in India, also states that Women are also expected to collect wood from fields. This wood is being used as a major fuel source for cooking. 
Clean drinking water is another major problem in rural areas. Like collection of wood, fetching water from remote areas is also the duty of women.

Table 6. Reproductive activity of the HHs by gender (\%)

\begin{tabular}{|l|c|c|c|c|c|c|c|c|}
\hline \multirow{2}{*}{\multicolumn{1}{|c|}{ Activities }} & \multicolumn{4}{c|}{ MHH } & \multicolumn{4}{c|}{ FHH } \\
\cline { 2 - 10 } & Men & Women & Both & Children & Men & Women & Both & Children \\
\hline Cleaning the house & 0.00 & 88.46 & 0.00 & 11.54 & 0.00 & 72.41 & 0.00 & 27.59 \\
\hline Cooking & 0.00 & 94.87 & 0.00 & 4.63 & 0.00 & 82.76 & 0.00 & 17.24 \\
\hline Fetching water & 0.00 & 88.77 & 0.00 & 19.22 & 0.00 & 67.24 & 0.00 & 32.75 \\
\hline Collecting fire wood & 11.54 & 46.15 & 24.36 & 17.94 & 0.00 & 81.03 & 0.00 & 18.95 \\
\hline Child care & 0.00 & 91.03 & 8.97 & 0.00 & 0.00 & 93.10 & 6.90 & 0.00 \\
\hline Washing cloth & 0.00 & 64.10 & 15.34 & 20.51 & 0.00 & 89.66 & 10.34 & 0.00 \\
\hline Boiling coffee/tea & 0.00 & 85.90 & 0.00 & 14.10 & 0.00 & 93.10 & 6.90 & 0.00 \\
\hline Cleaning utensils & 0.00 & 87.18 & 0.00 & 12.82 & 0.00 & 72.41 & 0.00 & 27.59 \\
\hline Buying food items & 0.00 & 78.21 & 17.94 & 0.00 & 0.00 & 98.28 & 0.00 & 1.72 \\
\hline Buying utensils & 3.85 & 82.05 & 17.75 & 0.00 & 0.00 & 98.28 & 0.00 & 1.72 \\
\hline Care for sick person & 0.00 & 56.41 & 43.58 & 0.00 & 0.00 & 96.55 & 3.44 & 0.00 \\
\hline Fencing & 83.30 & 0.00 & 16.66 & 0.00 & 41.38 & 32.66 & 25.86 & 0.00 \\
\hline House maintenance & 84.62 & 0.00 & 15.39 & 0.00 & 68.63 & 0.00 & 31.37 & 0.00 \\
\hline
\end{tabular}

Source: Own survey

\section{Community management role}

The major community roles performed in the society includes community meeting, funeral, planting tree on communal land, soil conservation, school building, road maintaining, church and mosque building, dispute resolution, attending wedding and religious ceremonies. These roles are unpaid and the societies devote labour and capital on voluntary basis. In the household meeting, funeral service, planting tree on communal land, soil conservation, school building, road maintaining, church and mosque building, dispute resolution were activities under taken by male in $\mathrm{MHH}$. Other roles such as wedding and religious ceremony were celebrated on equal basis. In $\mathrm{FHH}$, it was the responsibility of women performing all the activities. Except in funeral service in which followers of Muslim religious is prohibited, women are assisting in preparing food, boiling coffee, washing utensils, cleaning home and the surrounding (Table 7). The result shows a significant contribution of women in community management role and should serve as a good guide for research and development intervention.

Table 7. Community management role of the household (\%)

\begin{tabular}{|l|c|c|c|c|c|c|}
\hline \multirow{2}{*}{ Activities } & \multicolumn{3}{c|}{ MHH } & \multicolumn{3}{c|}{ FHH } \\
\cline { 2 - 7 } & Man & Women & Both & Man & Women & Both \\
\hline Meeting & 61.54 & 2.56 & 35.90 & 0.00 & 94.83 & 5.17 \\
\hline Funerals & 36.46 & 0.00 & 61.54 & 22.41 & 72.41 & 5.17 \\
\hline Tree plant & 64.20 & 0.00 & 35.89 & 0.00 & 100.00 & 0.00 \\
\hline Soil conservation & 61.54 & 0.00 & 38.46 & 0.00 & 81.03 & 18.97 \\
\hline School building & 66.67 & 0.00 & 33.33 & 0.00 & 82.76 & 17.24 \\
\hline Road maintaining & 79.49 & 0.00 & 20.51 & 0.00 & 81.03 & 18.97 \\
\hline Church and mosque building & 61.10 & 0.00 & 35.90 & 0.00 & 84.48 & 15.52 \\
\hline Attending wedding ceremony & 0.00 & 0.00 & 100.00 & 0.00 & 89.66 & 10.34 \\
\hline Attending religious ceremony & 0.00 & 0.00 & 100.00 & 0.00 & 89.66 & 10.34 \\
\hline Dispute resolution & 89.74 & 0.00 & 10.26 & 34.48 & 62.07 & 3.45 \\
\hline
\end{tabular}

Source: Own survey

\section{Intra household decision making of resources}

Decision is the final say in which the household tie up the issue considered. It creates inequality between male and female in the household. In MHH, men take the higher position regarding to type of crop cultivated, soybean production, livestock husbandry, and sell of farm produce and livestock (Table 8). Women decide in the purchase of house ware and joint decisions are made on social participation. In FHH women made the major decision and they consulted the son and in the case of polygamy arrangements they consult their husband in some cases. According to Abate (2019) findings in case of Delanta district, women have the secondary role in deciding what crops to plant, purchase of farm inputs, sale and purchase of large livestock, sale and rent farmland. These and other similar major economic decisions are either extremely dominated by husbands or are shared by both. Of course, there are some exceptions even in traditional times where women were able to make decision or influence the male's decision on economic and production related matters. These are sale and purchase of poultry and household items like salt, pepper, kerosene. The different types of activities and tasks are generally allocated to 
women and men within the family in terms of subsistence production and production for the market. Although these activities may be different, they have a social connectedness. Also the findings is similar with that of Mulgeta and Amsalu (2014) which indicate that rural women's participation in farm management decision making is quite minimal in the case of yilman district in Amhara region. Also the findings of frank (1999) in the study conducted in Amhara region found that married women have limited access to extension services, generally do not receive agricultural advice and have little decision-making power over household income or resources and on one hand women who head their own households are at an advantage in that if they own land.

Table 8. Intra household decision making in the household (\%)

\begin{tabular}{|l|c|c|c|c|c|c|}
\hline \multirow{2}{*}{\multicolumn{1}{c|}{ Activities }} & \multicolumn{3}{c|}{ MHH } & \multicolumn{3}{c|}{ FHH } \\
\cline { 2 - 7 } & Men & women & Both & Men & Women & Both \\
\hline Type of crop cultivated & 71.80 & 0.00 & 28.20 & 0.00 & 89.70 & 10.30 \\
\hline Soybean production & 76.90 & 0.00 & 23.10 & 0.00 & 91.40 & 8.60 \\
\hline Livestock husbandry & 69.20 & 0.00 & 30.80 & 0.00 & 86.20 & 13.80 \\
\hline Social participation & 0.00 & 0.00 & 100.00 & 0.00 & 93.10 & 6.90 \\
\hline Sell of farm produce & 64.10 & 0.00 & 35.90 & 0.00 & 87.90 & 12.10 \\
\hline Sell of livestock & 73.10 & 0.00 & 26.90 & 0.00 & 86.20 & 13.80 \\
\hline Purchase of house ware & 0.00 & 79.50 & 20.50 & 0.00 & 94.00 & 5.20 \\
\hline
\end{tabular}

Source: Own survey

Daily activity profile

The labour participations in both productive and reproductive activities were further identified in the study area .Women in both households spent longer time in reproductive and domestic tasks. Thus women are busier throughout the day. According to the respondents in both households the majorities of women wake up before 6 O'clock, in the crack of early and go to bed after 10 O'clock in the night. Based on the survey result (Table 9) the contribution of men in reproductive activities was rare, they spent the larger time on productive activity accounted for 10 hours per day. Whereas women in MHH spent nine hours per day in reproductive activity and they spent six hours per day in productive activity. Women in FHH spent eight hours per day in each activity. Generally women in MHH spent a total of 15 hours per day whereas women in FHH spent a total of 16 hours per day. Considering the time spent by men in $\mathrm{MHH}$ it was accounted a total of 11 hours per day. Rural women have very hectic life. Her work starts from dawn and ends at dusk. The daily routine work begins from house cleaning, fetching drinking water, dish washing, laundry, preparing food for family, care of children, tailoring and sewing clothes. She manages these activities very smartly (lal and Khurana 2011). Women work longer hours than men in most developing countries when both paid and unpaid works are taken into consideration. However, much of their work remains undervalued because it is unpaid and confined to the domestic sphere (FAO; IFAD; ILO, 2010). Table 9. The mean hours devoted by households

\begin{tabular}{|l|c|c|c|}
\hline \multirow{2}{*}{ Tasks } & \multicolumn{2}{|c|}{ MHH } & FHH \\
\cline { 2 - 4 } & Husband & Wife & Female \\
\hline Reproductive & 1 & 9 & 8 \\
\hline Productive & 10 & 6 & 8 \\
\hline Total & 11 & 15 & 16 \\
\hline
\end{tabular}

Source: Own survey

\section{Conclusion}

In MHH and FHH there was varied involvement of household members in various farm activities. Male and female in $\mathrm{MHH}$ and $\mathrm{FHH}$ was undertaking land preparation activities; the difference was women never plough using oxen in both households. While in case of land preparation by hand digging they were taken part in the activities. In addition to considerable agricultural production activities both men and women undertake in reproductive and community management role. Women in both $\mathrm{MH}$ and FH households were over burden and worked more hours than men.

\section{References}

Abate, N. (2019). Rural Women Participation in Decision-Making Power and Natural Resource Management in Ethiopia: A Case of Delanta District, South Wello Zone. EC Agriculture, 5.

Adisa, R. S., \& Balogun, K. S. (2013). Impact of improved technologies on small-scale soybean production: empirical evidence from Benue State, Nigeria. Pak. J. Agri. Sci, 50(2), 305-310.

Agado, M. O., \& Ejembi, E. P. (2010). Gender roles in soybean cultivation in central Benue State, Nigeria. Nigerian Journal of Rural Sociology, 11(2202-2019-1053), 116-123.

Ardayfio-Schandorf, E., \& Awumbila, M. (2000). Gender and agrodiversity in southern Ghana: preliminary 
findings. PLEC News and Views, 15, 23-26.

Aregu, L., Puskur, R., \& Bishop-Sambrook, C. (2011). The role of gender in crop value chain in Ethiopia.

Asres Elias, Nohmi, M., Yasunobu, K., \& Ishida, A. (2015). Does gender division of labour matters for the differences in access to agricultural extension services? A case study in North West Ethiopia. Journal of agricultural science, 7(1), 138.

Balogun, K. S., Adisa, R. S., Yinusa, R., Abdulahamid, A. T., \& Ayinla, R. A. (2014). Evidence of Gender Role in Soybean Production: Case Study from Agrarian Communities in Benue state, Nigeria. Ethiopian Journal of Environmental Studies and Management, 7(1), 59-64.

Bambasi District Agricultural Office (BDAO), 2016. Annual report.

Chanyalew, D., Adenew, B., \& Mellor, J. (2010). Ethiopia's agricultural sector policy and investment framework (PIF) (2010-2020), Draft final report. Federal Democratic Republic of Ethiopia, Ministry of Agriculture and Rural Development. Addis Ababa.

CIA (Central Intelligence Agency) (2019). World factbook and other sources. https://theodora.com/wfbcurrent/ethiopia/ethiopia_economy.html. Accessed 8 February 2019

CRS (Catholic Relief Service) (2013). A sample survey for gender analysis. https://www.crs.org/.../a-samplegender-analysis.pdf

Ejembi, E. P., Omoregbee, F. E., \& Ejembi, S. A. (2006). Farmers' assessment of the training and visit extension system in central Nigeria: Evidence from Barkin Ladi, Plateau State. Journal of Social Sciences, 12(3), 207212.

Fajarwati, A., Mei, E. T. W., Hasanati, S., \& Sari, I. M. (2016). The productive and reproductive activities of women as form of adaptation and post-disaster livelihood strategies in Huntap Kuwang and Huntap Plosokerep. Procedia-Social and Behavioral Sciences, 227, 370-377.

FAO (Food and Agriculture Organization) (2011b).The State of Food and Agriculture 2010-11: Women in Agriculture: Closing the Gender Gap for Development.

FAO (Food and Agricultural Organization of the United Nation). (2011a). FAO at Work 2010-2011: Women Key to Food Security. FAO, Rome.

FAO; IFAD; and ILO (2010).Gender dimension of Agricultural and Rural Employment: Differentiated path ways out of poverty, Status, Trends and Gaps, Rome, Geneva.

Farré, L. (2013). The role of men in the economic and social development of women: Implications for gender equality. The World Bank.

Frank, E. (1999). Gender, agricultural development and food security in Amhara, Ethiopia: The contested identity of women farmers in Ethiopia. USAID/Ethiopia.

Hanna, K. (1990). Gender Relations in Mobilizing Human Resources ${ }^{e e}$ in S. Pausewang et al., Ethiopia: Rural Development Options, London.

Haregewoin, C., \& Emebet, M. (2003). Towards gender equality in Ethiopia, a Profile of gender Relations. Sweden: Swedish International Development Cooperation Agency, 11.

Lal, R., \& Khurana, A. (2011). Gender issues: The role of women in agriculture sector. Int. J. Business Econ. Manage. Res, 1(1), 29-39.

Mohammed, B. T., \& Abdulquadri, A. F. (2012). Comparative analysis of gender involvement in agricultural production in Nigeria. Journal of Development and Agricultural Economics, 4(8), 240-244.

Mollel, N. M., \& Mtenga, N. A. (2000). Gender roles in the household and farming systems of Tchenzema, Morogoro-Tanzania. South African Journal of Agricultural Extension, 29(1), 73-88.

Mulugeta, M., \& Amsalu, T. (2014). Gender, participation and decision making process in farming activities: The case of Yilman Densa District, Amhara Region, Ethiopia. J. Econ. Sustain. Develop, 5(1), 28-34.

Ogato, G. S., Boon, E. K., \& Subramani, J. (2009). Gender roles in crop production and management practices: a case study of three rural communities in Ambo district, Ethiopia. Journal of human ecology, 27(1), 1-20.

Ragasa, C. (2012). Gender and institutional dimensions of agricultural technology adoption: a review of literature and synthesis of 35 case studies (No. 1007-2016-79530).

USAID (2013). Empowering women through agricultural development in Ethiopia. http://www.usaid.gov

World Bank (2010). Gender and governance in rural services: insights from India, Ghana, and Ethiopia. Washington DC, USA: W. Bank.

Yemane, T.1967.Statistics; An Introductory Analysis, 2nd (ed).New York, Harper and Row publisher. 